Original article

Reprint

\title{
Complications after different surgical methods for suburethral implantation of polypropylene slings in women with stress urinary incontinence
}

\author{
Igor A. Eizenakh ${ }^{1}$, Olesiya S. Korotkevich ${ }^{2}$, Vadim G. Mozes³, Veronika V. Vlasova ${ }^{4}$ \\ ${ }^{1}$ Novokuznetsk City Clinical Hospital No. 1, Novokuznetsk, Russia \\ ${ }^{2}$ Novokuznetsk City Clinical Hospital No. 29, Novokuznetsk, Russia \\ 3 Kemerovo State Medical University, Kemerovo, Russia \\ ${ }_{4}$ Kemerovo Regional Clinical Hospital, Kemerovo, Russia
}

Received 13 February, 2018, Accepted 21 January, 2020

Original Text (C) Eisenakh I.A., Korotkevich O.S., Mozes V.G., Vlasova V.V., 2018, published in Saratov Journal of Medical Scientific Research 2018; 14 (2): 277-280

(C) 2020, Eisenakh I.A., Korotkevich O.S., Mozes V.G., Vlasova V.V.

(C) 2020, Saratov Medical Journal

\begin{abstract}
:
Objective: to identify the proportion of complications after suburethral implantation of polypropylene slings in women with stress urinary incontinence based on a seven-year experience.

Material and Methods. We conducted the analysis of a seven-year experience in various implantation techniques of suburethral slings in 1260 women with stress urinary incontinence: inside-out and outside-in obturator sling fixation; suprapubic sling fixation and non-trocar mini-sling installment.

Results. The highest incidence of complications was observed over the first two years after suburethral sling implantation was performed. Subsequently, the proportion of complications declined progressively to the lower limit values of 7-8\% in the course of three last years. An incidence of early surgical complications among various suburethral sling implantation techniques had no statistically significant differences. However, after the suprapubic sling implantation, intraoperative and mesh-associated complications prevailed.

Conclusion. Our study confirmed that suburethral sling implantation using suprapubic fixation method was associated with a higher incidence of complications and should have been performed exclusively for the target group of the patients, for whom safer surgical procedures were contraindicated.
\end{abstract}

Keywords: stress urinary incontinence, suburethral polypropylene sling.

Cite as Eisenakh IA, Korotkevich OS, Mozes VG, and VV Vlasova. Complications after different surgical methods for suburethral implantation of polypropylene slings in women with stress urinary incontinence. Saratov Medical Journal 2020; 1(1): e0105

Correspondence to Vadim G. Mozes. Tel.: +79045732443. E-mail: vadimmoses@mail.ru

\section{Introduction}

Despite the progress made by contemporary medicine, urinary incontinence still remains unresolved problem. Recent epidemiological studies demonstrated that urinary incontinence symptoms were experienced at least once a year by $5-69 \%$ of women and $1-39 \%$ of men [1]. Due to specific anatomical and physiological traits of female urogenital system, such symptoms were twice as frequent in women as in men, making urinary incontinence a «female problem». Stress urinary incontinence is not a life-threatening or dangerous condition, but it significantly impairs the patient's life quality and urges doctors to search for new treatment options. The conventional method of stress urinary incontinence treatment involves a surgery leading to artificial development of fascia accompanied by formation of new fulcrum and pelvic floor support [2]. Use of synthetic materials was a revolutionary step in surgical treatment of this condition. Currently, the most commonly used invasive technique for stress urinary incontinence is the suburethral implantation of polypropylene sling with transobturator or suprapubic fixation. However, this surgical approach leaves some controversial issues including tissue reaction to synthetic materials and risk of certain complications, such as vaginal and bladder erosions, dyspareunia, pain, vaginal synechia, infection, sling migration, etc. [3].

Objective: to determine the rate of post-surgical complications from the seven-year data analysis of different suburethral implantation techniques of polypropylene slings.

\section{Materials and methods}

We performed the retrospective analysis of the seven-year experience on surgical treatment of a stress urinary incontinence. Women were treated in the following urological hospital wards: Novokuzntesk City Hospital No.1; Regional Clinical Center for Miners' Healthcare; M.A. Podgorbunsky Regional Clinical Emergency Hospital, S.V. Belyaev Regional Clinical Hospital, Prokopievsk City Hospital No.1.

In 2011-2017, there were 1260 women surgically treated for stress urinary incontinence. Their ages ranged 36-67 years old. All patients were distributed among four groups based on applied technique of suburethral implantation of a polypropylene swing-mesh (THT Bio-Science) with a mass of $28 \mathrm{~g} / \mathrm{m} 2)$. Treatment group $1(\mathrm{n}=756)$ had an inside-out 
obturator sling implantation, while group $2(n=294)$ was characterized by an outside-in obturator sling implantation; group $3(n=126)$ and group $4(n=84)$ had suprapubic sling implantation and non-trocar mini-sling installment, respectively.

All patients underwent standard pre-surgical care along the guidelines of the Russian Ministry of Health Management (order No.595n). Surgeries were performed with a spinal anesthesia, based on standard procedures and in conjunction with medical necessity. Rates of intra-operative, early postoperative and mesh-associated complications, along with overall complications' rate over the 7-year period of time were evaluated.

Sample variables shown in the tables below are accompanied by indicated sample sizes (n) and probabilities (p) of null hypotheses being true. Statistical significance of differences between relative frequencies of two or more events was assessed using a chi-square criterion. The critical level of significance for testing statistical hypotheses was considered at 0.05 .

\section{Results}

The highest complication rate was observed during the first two years after initial polypropylene suburethral mesh was installed. Later on, incidence of complications was progressively diminishing. It remained stable at 7-8\% level over the last three years (Table 1).

Intraoperative complications, such as bladder injury, were significantly more prevalent in the patients undergoing suburethral implantation of polypropylene sling by using a suprapubic technique (Table 2). Incidence of early postoperative complications at various techniques of suburethral polypropylene sling implantation had no statistically significant difference. Mesh-associated complications, such as a bladder erosion, were statistically more prevalent in the patients after suburethral polypropylene sling implantation using the suprapubic method.

\section{Discussion}

Surgical treatment of pelvic prolapse using synthetic mesh implants is a promising and progressively improving reconstructive technique [4]. A method of choice for the treatment of stress urinary incontinence in women is the suburethral tape implantation. It has a lasting beneficial effect, being a relatively simple, minimally invasive and inexpensive procedure [5]. However, like any surgical intervention, suburethral implantation of a polypropylene sling is associated with a risk of complications depending on a surgeon's experience, individual anatomical features and tissue reactivity towards synthetic materials.

Table 1 . Overall rate of complications over 7 years

\begin{tabular}{|l|c|c|c|c|c|c|c|}
\hline \multicolumn{1}{|c|}{ Parameter } & 2011 & 2012 & 2013 & 2014 & 2015 & 2016 & 2017 \\
\hline $\begin{array}{l}\text { Number of } \\
\text { patients }\end{array}$ & 139 & 165 & 198 & 243 & 227 & 199 & 89 \\
\hline $\begin{array}{l}\text { Complication } \\
\text { rate, \% }\end{array}$ & $25.9^{*}$ & 20.6 & 13.1 & 8.6 & 7.9 & 7 & 7.8 \\
\hline
\end{tabular}

${ }^{*} \mathrm{p}<0,05$ between 2011 and 2013-2017.
It is worth noting that a surgeon's experience turned out to be crucial for decreasing an occurrence of complications. Our study has shown that refining practical skills allows to reduce complication occurrence by 3 times.

Our experience confirmed the point of view of A.I. Neymark, who opined that an alternative way to decrease the complication rate was to follow the principle of using the most appropriate suburethral tape placement technique for each individual patient [6]. Specifically, using this principle allowed the author to lower the rate of complications down to $3 \%$. Most researchers recognize that every technique has its own benefits and flaws, thus being suitable just for a specific target group of the patients [7].

Non-trocar mini-sling implantation is used at light stages of this medical condition, in the patients with relatively low body mass. That is why it is rarely associated with intraoperative and early postoperative complications, which is confirmed by our data and literature sources [8].

In-out and out-in modifications of obturator sling implantation are used at moderate manifestations of discussed condition, being simple and having a good corrective effect. However, they require longer time to separate anterior vaginal wall from urinary bladder. The observed results are consistent with published data showing minor frequencies of intraoperative and postoperative complications in such patients [9].

Table 2. Occurrence of intraoperative, early postoperative and mesh-associated complications, \%

\begin{tabular}{|l|c|c|c|c|}
\hline Complications & $\begin{array}{c}\text { Group 1 } \\
(\mathrm{n}=756)\end{array}$ & $\begin{array}{c}\text { Group 2 } \\
(\mathrm{n}=294)\end{array}$ & $\begin{array}{c}\text { Group 3 } \\
(\mathrm{n}=126)\end{array}$ & $\begin{array}{c}\text { Group 4 } \\
(\mathrm{n}=84)\end{array}$ \\
\hline \multicolumn{5}{|c|}{ Intraoperative complications } \\
\hline Bladder injury & 1.58 & 1.36 & $7.9^{*}$ & 0 \\
\hline Peritoneal injury & 0 & 0 & 1.6 & 0 \\
\hline $\begin{array}{l}\text { Bleeding (blood loss over } \\
\text { 200 ml) }\end{array}$ & 1.05 & 1,7 & 4.76 & 1.19 \\
\hline Labial / fornical injury & 0.93 & 1.7 & 0 & 0 \\
\hline
\end{tabular}

\begin{tabular}{|c|c|c|c|c|}
\hline & 0.93 & 1.7 & 0 & 0 \\
\hline \multicolumn{5}{|c|}{ Early postoperative complications } \\
\hline Infection & 0.26 & 0 & 0 & 0 \\
\hline $\begin{array}{l}\text { Hematoma (volume }>300 \\
\mathrm{ml} \text { ) }\end{array}$ & 1.5 & 2.72 & 3.17 & 2.4 \\
\hline Micturition disorders & 3.7 & 4.1 & 4 & 1.19 \\
\hline \multicolumn{5}{|c|}{ Mesh-associated complications } \\
\hline Bladder erosion & 1.85 & 1.7 & $8.7^{*}$ & 1.19 \\
\hline
\end{tabular}


Suprapubic sling placement is recommended for the patients with severe symptoms, recurrent cases, as well as the presence of significant comorbidities and a high body mass. One of the studies showed that the patients prescribed to have a suprapubic sling placement has a high risk of intraoperative and mesh-associated complications [10].

\section{Conclusion}

Our data confirmed that suburethral sling placement with suprapubic fixation was associated with a higher risk of complications. Thus its use was only justified in selected patients, for whom application of safer techniques was not feasible.

Conflict of interest: none stated.

\section{References}

1. Lucas MG, Bedretdinova D, Berghmans LC, et al. Guidelines on Urinary Incontinence. European Association of Urology 2015; 75 https://uroweb.org/guideline/urinary-incontinence/

2. Maher C, Feiner B, Baessler K, et al. Surgical management of pelvic organ prolapse in women. Cochrane Database Syst Rev 2013; 4: CDoo4014.

http://dx.doi.org/10.1002/14651858.CDo12376

3. Shaikh S, Ong EK, Glavind K, et al. Mechanical devices for urinary incontinence in women. Cochrane Database Syst Rev 2006; 3: CDoo1756.

http://dx.doi.org/10.1002/14651858.CDoo1756.pub6

4. Herbison GP, Arnold EP. Sacral neuromodulation with implanted devices for urinary storage and voiding dysfunction in adults. Cochrane Database Syst Rev 2009; 2: CD004202.

http://dx.doi.org/10.1002/14651858.CD004202.pub2

5. Haylen BT, Freeman RM, Swift SE, et al. An International Urogynecological Association (IUGA). International Continence Society (ICS) joint terminology and classification of the complications related directly to the insertion of prostheses (meshes, implants, tapes) and grafts in female pelvic floor surgery. Neurourol Urodyn 2011; 30(1): 2-12.

http://dx.doi.org/10.1002/nau.22199

6. Niemark AI, Razdorskaya MV, Neimark BA. Correction of stress urinary incontinence in women with a suburethral meshes. Kazan Medical Journal 2012; 93(3): 538-542. https://doi.org/10.17816/KMJ1889

7. Eizenakh IA, Vlasova VV, Mozes VG, et al. Early postoperative mesh-related complications after placing two-and four-sleeved synthetic of implants women with genitals prolapse. Medicine in Kuzbass 2017; 1(16): 12-18.

https://cyberleninka.ru/article/n/rannie-meshassotsiirovannye-posleoperatsionnye-oslozhneniya-priustanovke-sinteticheskih-setchatyh-implantov-s-dvumya-ichetyrmya

8. Nygaard IE, Shaw JM. Physical activity and the pelvic floor. Am J Obstet Gynecol 2016; 214(2): 164-171.

http://dx.doi.org/10.1016/j.ajog.2015.08.067

9. Wein AJ. Tension-Free Vaginal Tape-Obturator for Treatment of Pure Urodynamic Stress Urinary Incontinence: Efficacy and Adverse Effects at 10-Year Follow-up. J Urol 2018; 199(2): 347348.

10. Rautenberg O, Zivanovic I, Kociszewski J, et al. Current Treatment Concepts for Stress Urinary Incontinence. Praxis (Bern 1994) 2017; 106(15): 1-8. http://dx.doi.org/10.1024/1661$\underline{8157 / a 002843}$

\section{Authors:}

Igor A. Eizenakh - PhD, urologist, Novokuznetsk City Clinical Hospital No. 1, Novokuznetsk, Russia;

Olesiya S. Korotkevich - MD, obstetrician-gynecologist, Novokuznetsk City Clinical Hospital No. 29, Novokuznetsk, Russia; Vadim G. Mozes - DSc, Chair of the Department of Obstetrics and Gynecology No. 1, Kemerovo State Medical University, Kemerovo, Russia;

Veronika V. Vlasova - PhD, obstetrician-gynecologist, Kemerovo Regional Clinical Hospital, Kemerovo, Russia. 